\title{
Fermentology • Fermentology
}

\section{Honey, Toxicity, and}

Intoxication: A 40,000 Year

History of Mead in

Southern Africa?

Neil Rusch $^{1}$, Kelsey Dufresne ${ }^{2}$

${ }^{1}$ University of the Witwatersrand, ${ }^{2}$ North Carolina State University

Published on: Dec 03, 2021

DOI: $10.52750 / 846227$

License: Creative Commons Attribution 4.0 International License (CC-BY 4.0). 
Editors note: This publication contains the video of the talk from the Fermentology webinar series, as well as a lightly edited transcript of the lecture. The transcript has been enriched with media, annotations, and links to other material by the digital publication team in order to amplify and extend the content for a reading experience.

\section{Abstract}

Three ingredients exist inside any honeybee hive, wild or domesticated - yeast, beebread (transformed floral pollen) and honey (fructose and glucose). If combined with water, these ingredients produce alcohol. Success depends on an accumulation of pharmacological knowledge, keen observation and an astute but flexible cognitive ability. Archaeological evidence from Border Cave, South Africa suggests that honey bee products were being used and consumed by early people 40,000 years ago. In this presentation, Neil Rusch draws on the archaeological record in support of a long-term chronology involving bees and cognitive development. This better explains the early appearance of intentional fermentation. A deep time perspective also accounts for the occurrence of bees in the ethnography, rock paintings and mythology of the region.

\section{Watch the talk}

Visit the web version of this article to view interactive content. A 40,000 Year History of Mead in Southern Africa with Neil Rusch

\section{Introduction}

In this presentation I intend making a link between bow hunting and intoxication. In doing so I hope to demonstrate that beneath the nominalism of naming, there's a much deeper connection than the lexical association.

I'll also describe a fermentation experiment. One result of the experiment was a 'spiked,' alcoholic-honey drink. The procedure requires double fermentation - the first fermentation ('sweat') enhances the alkaloid contained in the plant additive. The secondary fermentation produces the alkaloid-enhanced alcohol. 


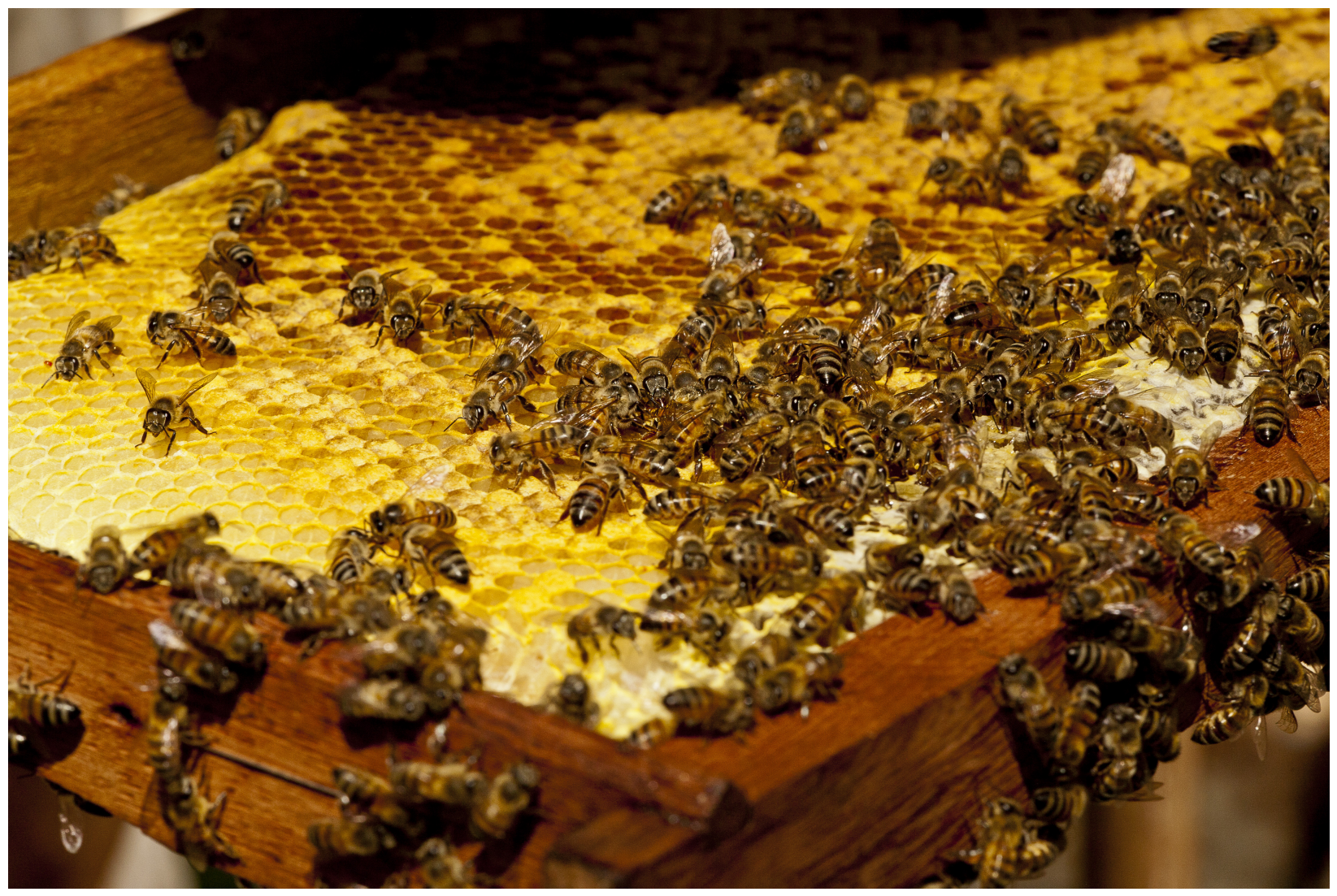

Swarm of Africanized honey bees" by Jonathan Wilkins (CC BY-SA 3.0).

\section{First, the Basics}

First, let's remind ourselves what we find in a beehive. $\underline{1}$ Honeybees were part of the Paleoscape since before the advent of Homo sapiens. Honey was surely a catalyst, allowing first fermentation to happen when modern humans arrived on the scene. 


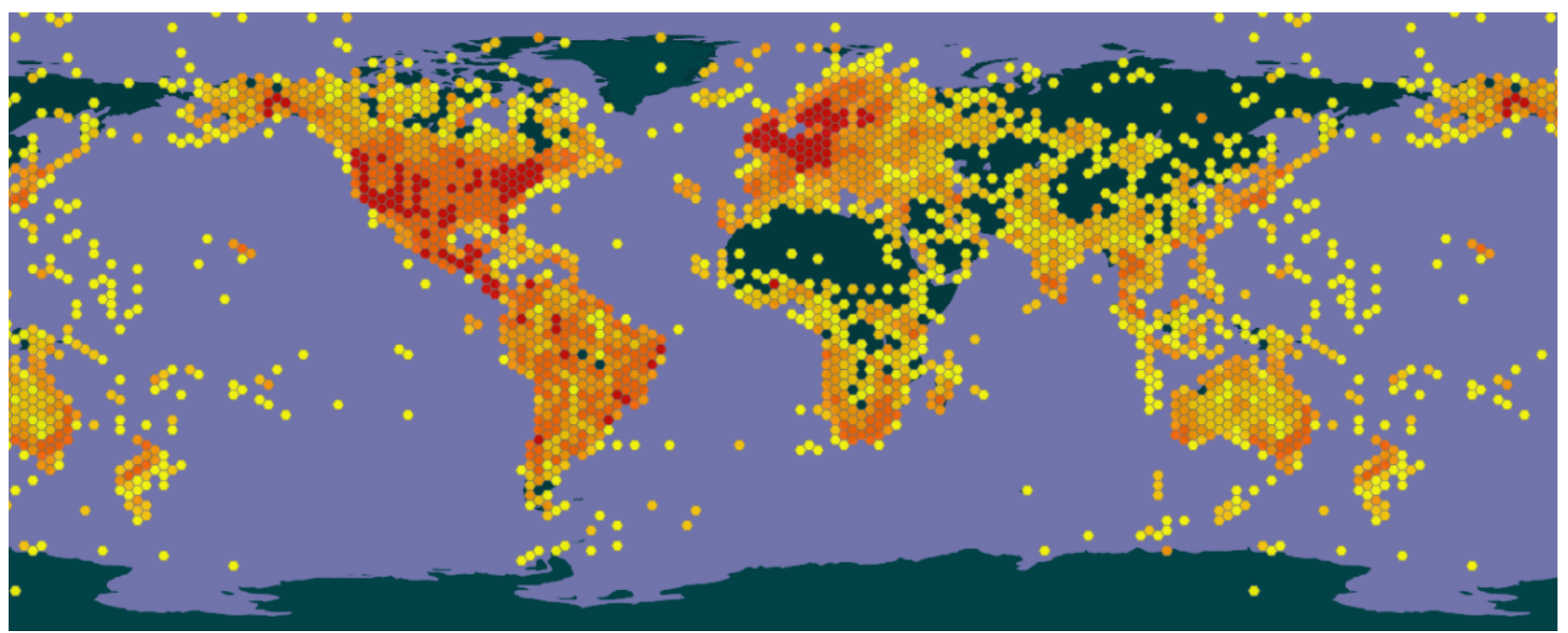

2, $\underline{931}, 221$ georeferences of Apidae family, (c) OppenStreetMap contributors, (c) OpenMapTiles, GBIF.

Click to view the interactive map.

Three ingredients exist inside any honeybee hive, wild or domesticated:

1. Yeast[1]

2. Beebread (transformed floral pollen)[2]

3. Honey (fructose and glucose)

Given the right conditions, if these three ingredients are combined with water, they produce alcohol.

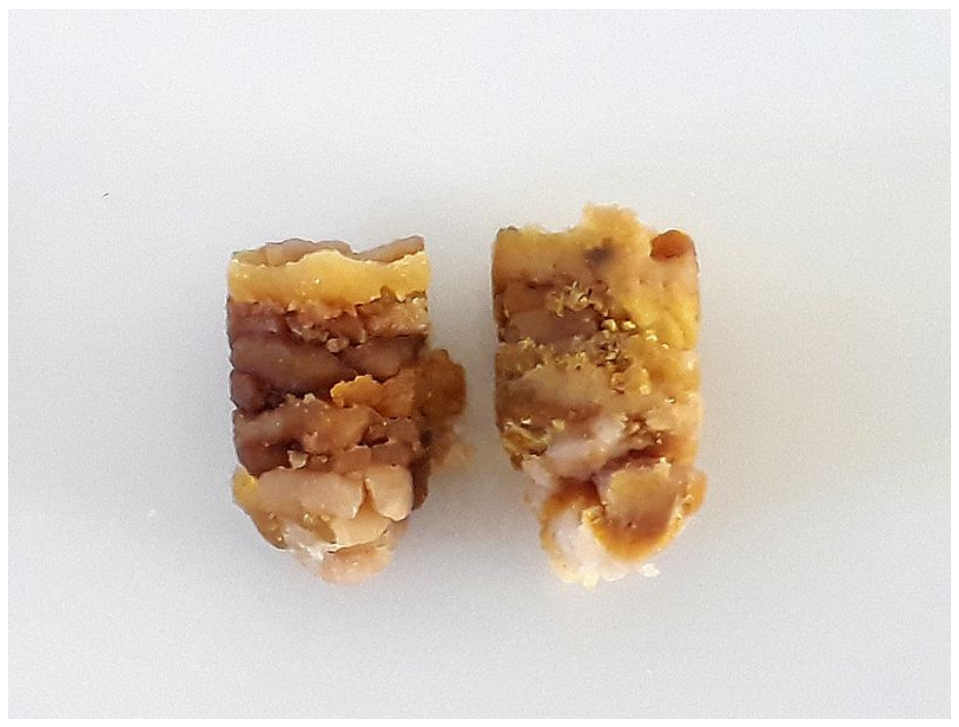

Bee bread made of pollen collected from a hive, photo by Neil Rusch 
Alcohol can be discovered accidentally in the wild and then opportunistically exploited. For example, in Southern Angola, !Xun-speaking San-Bushmen seek out bee hives in Baobab trees that have been inundated by rain. The bees abscond, leaving behind a cache of honey-alcohol in the tree cavities. We can assume that discovering these naturally occurring fermentations then led to the earliest fermentation attempts.

\section{Honey and Fermentation}

Researchers have highlighted the nutritional importance of honey in paleo diets and for human evolution. It seems to be accepted that alcohol is a sure sign for evolving social behavior.

Likewise, the intentional use of fermentation is a marker for human cognitive development. Therefore, there are basically two areas of research :

1. On the one hand, there's the "drunken monkey" hypothesis. These include investigations into primate adaptation and the predilection for fermented fruit.

\section{Visit the web version of this article to view interactive content.}

\section{Why do we drink alcohol? The Drunken Monkey Argument}

2. The other avenue focuses on finding traces of alcohol through residue analysis of excavated containers.

One problem is that there is a vast time gap between the "drunken monkey" and the appearance of containers in the archaeological record. Organic containers don't survive 25 to 50, 000 years. In other words, organic containers that may have provided traces of alcohol are erased from the record.

The earliest evidence of honeybee exploitation anywhere was excavated at Border Cave, which is on the border between South Africa and Eswatini. $\underline{2}$ 


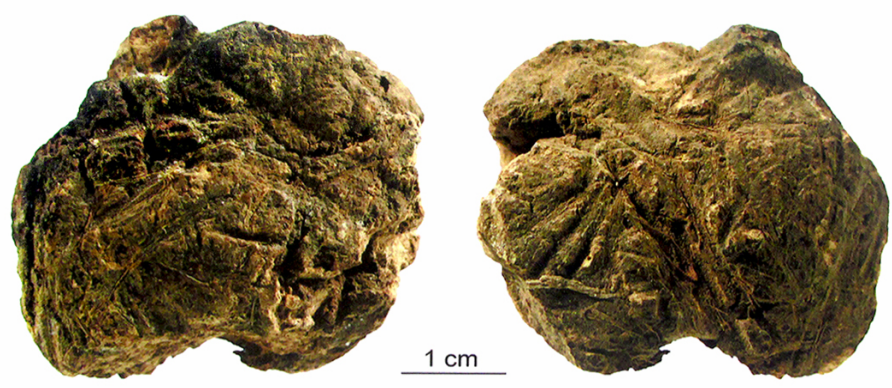

Two sides of a lump of beeswax containing Euphorbia tirucalli resin and possibly egg, bound with vegetal twine, from Border Cave, 41-39 000 years ago

Photo: Francesco d'Errico and Lucinda Bachwell

Image included in Supplementary Material for d'Errico F, Backwell L, Villa P, et al. Early evidence of San material culture represented by organic artifacts from Border Cave, South Africa. Proceedings of the National Academy of Sciences of the United States of America. 2012 Aug;109(33):13214-13219. DOI: 10.1073/pnas.1204213109. (c) The Authors
This beeswax provides proof that at 40,000 years ago, there was knowledge about bees - and that bee products were being used and consumed. Therefore, the research question really is: Could controlled fermentation have occurred in southern Africa 25,000 to 50,000 years ago? What evidence could there be, other than containers? 


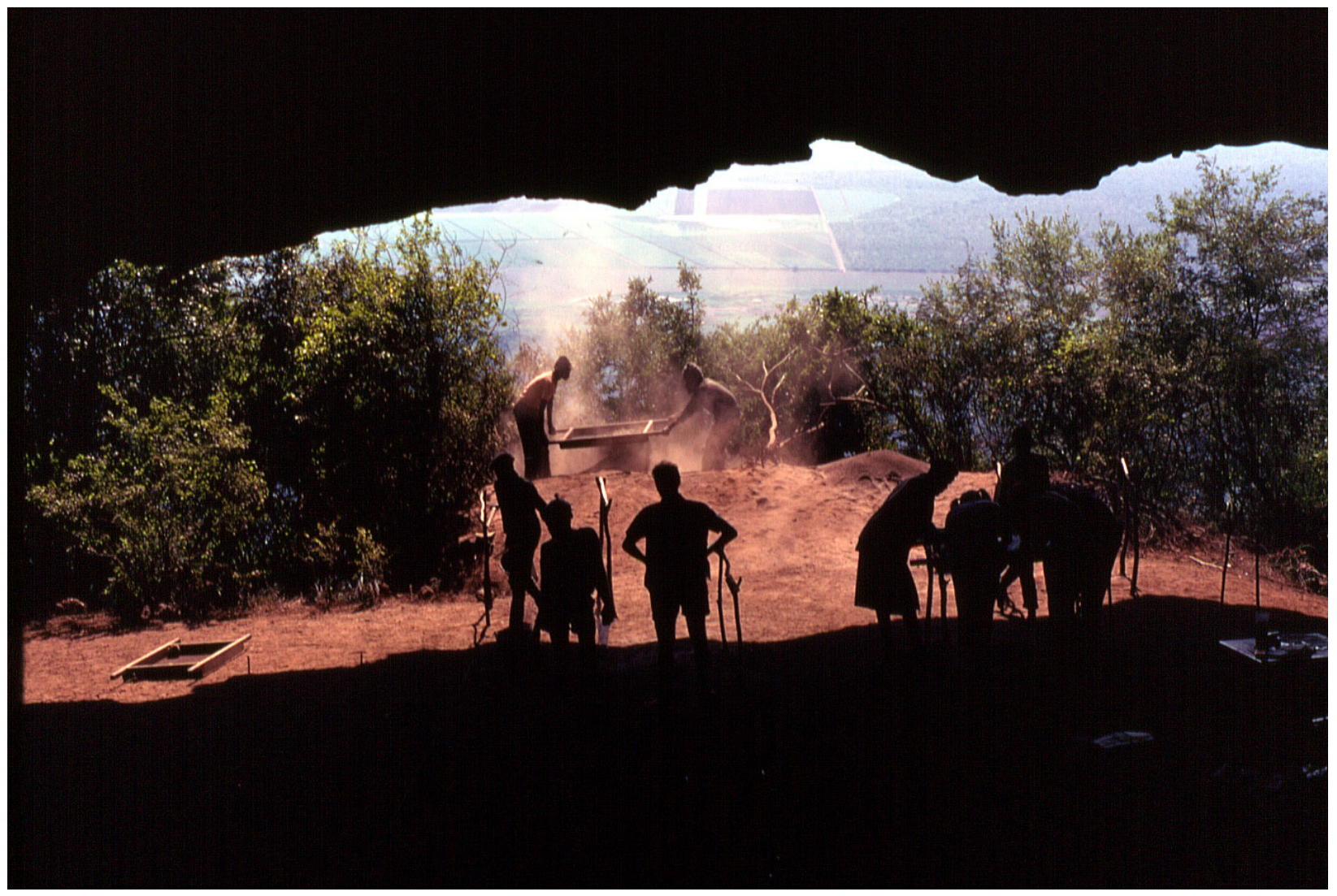

Sifting of deposits at mouth of Border Cave, near Ingwavuma by Androstachys (public domain)

With honey, we have the material ingredients to make alcohol. But what about the intangible ingredients?

In addition, a package of cognitive attributes was necessary to enact the next step: advanced planning, task switching, working memory, and so forth, were also necessary requirements. 


\section{Archaeological Sites}

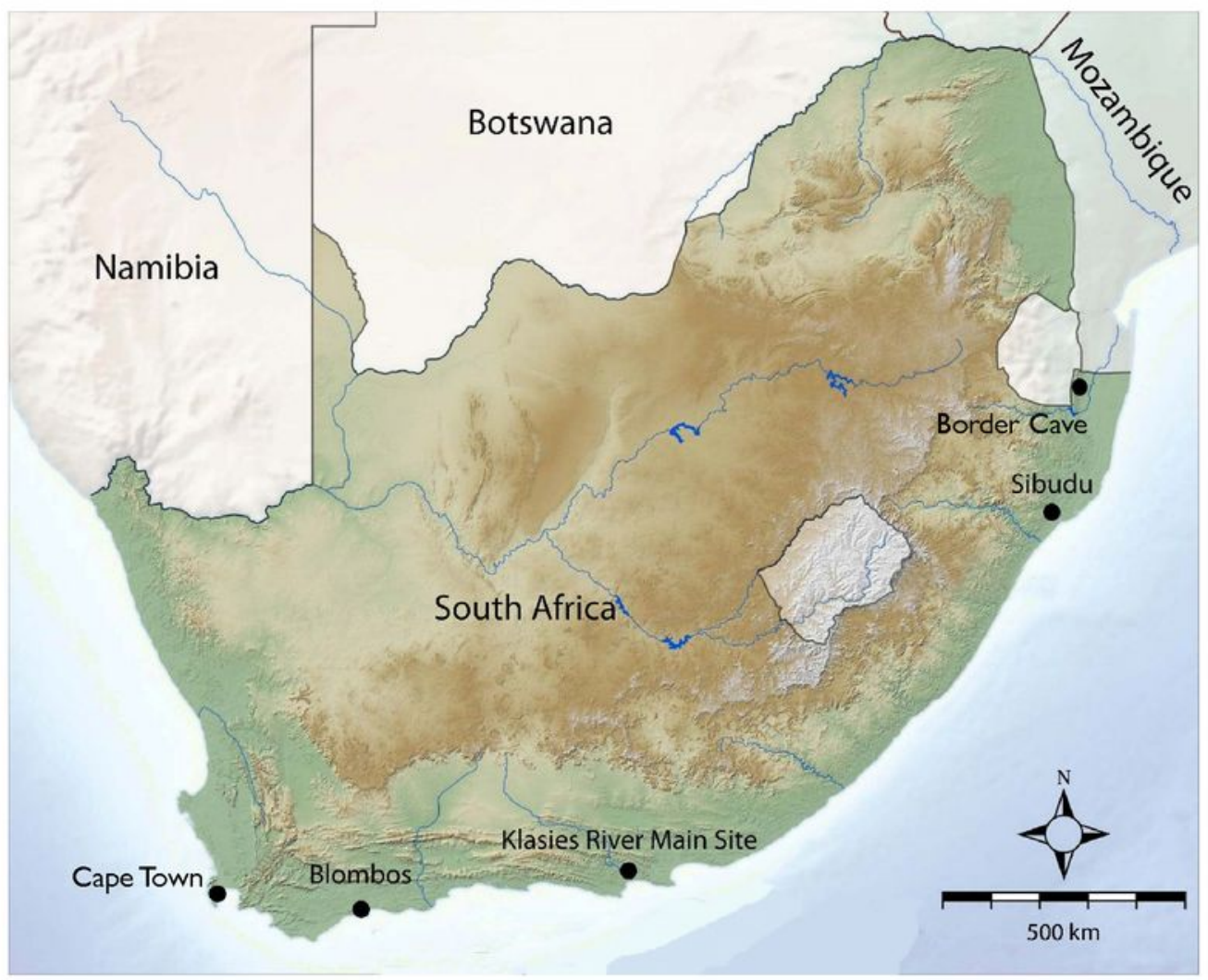

Map of archaeological sites provided by Neil Rusch.

We have complex techno-behavior, which is archaeologically recognizable in the Middle Stone Age in Southern Africa. For example, ochre compounds interpreted as paint were used 100,000 years ago at Blombos. Arrow poison used 60,000 years ago at the Sibudu, Klasies River, and Border Cave archaeological sites. Compound adhesive has been found to have been used 58,000 to 70,000 years ago. 


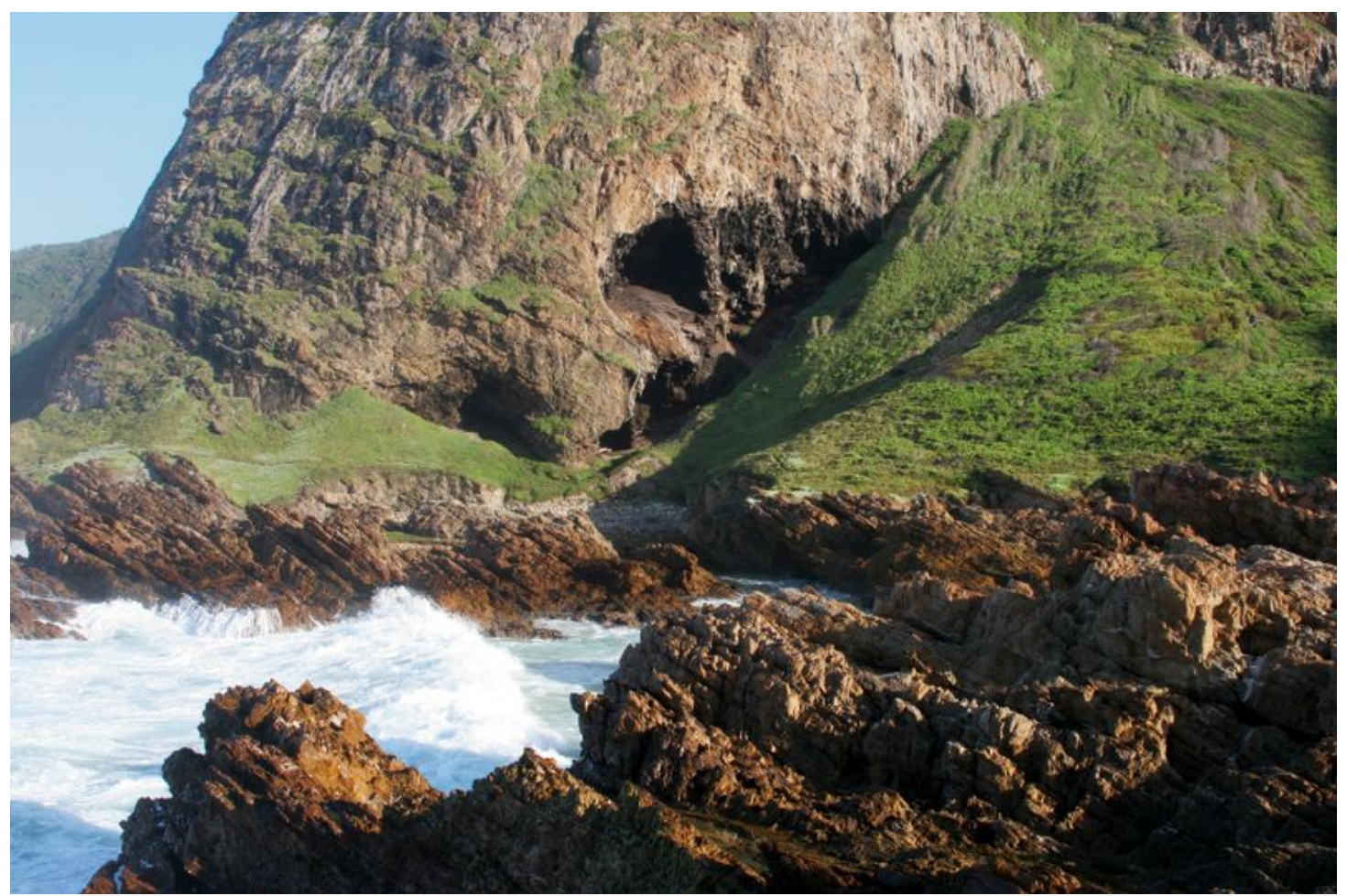

Klasies River archaeological site. Image source: Neil Rusch personal archive.

This is compelling evidence that there was, way back then, complex cognition and fluid thinking. As such, fermentation sits comfortably within these techno-behaviors. But it leaves no archaeological trace, certainly not at the time depth we are considering here. However, much like arrow poison and compound adhesive, fermentation also requires the combination of several substances to produce a novel product. 


\section{Bow Hunting and Fermentation}

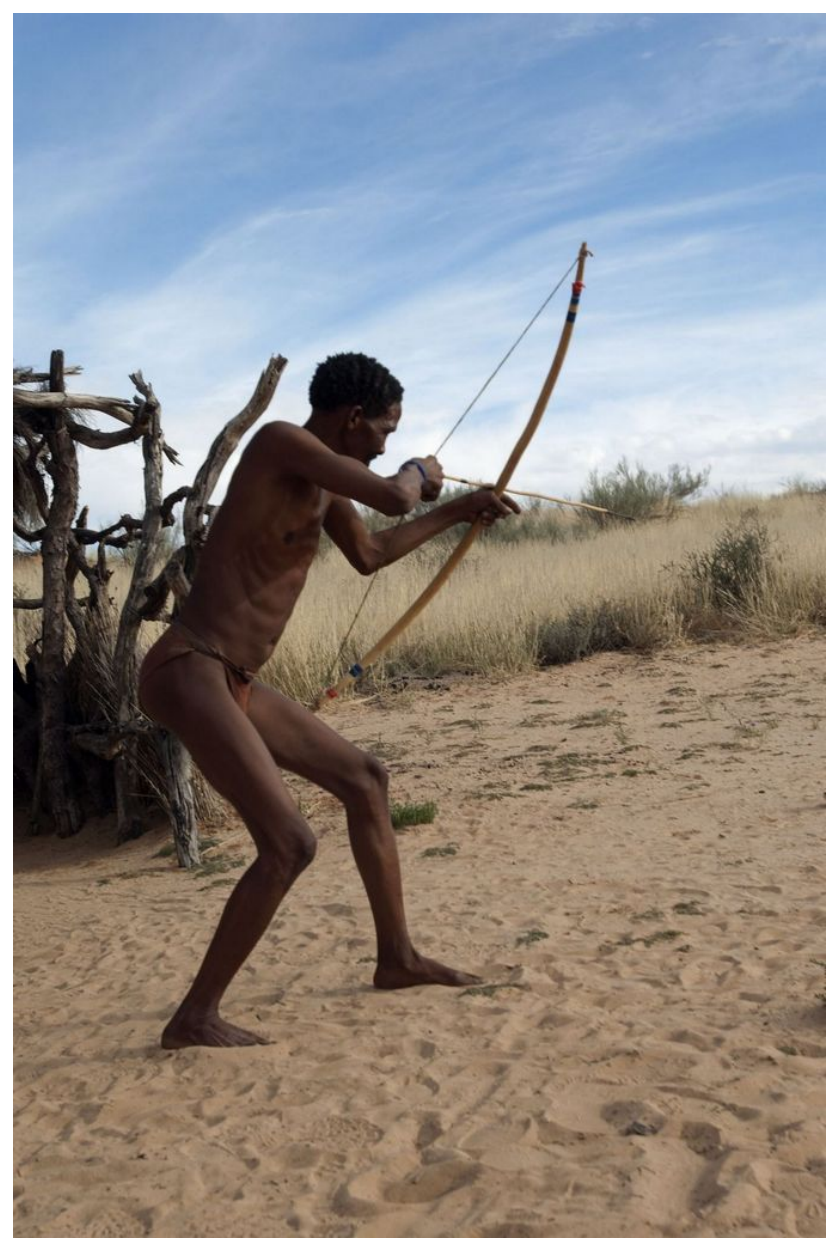

"Bushmen showing how he hunts with a bow and arrow at the Bushman cultural village, near Xaus Lodge, Kgalagadi Transfrontier Park, Northern Cape, South Africa. Vue de Northern Cape en Afrique du Sud."

"South African Tourism from South Africa," 2 May 2009, CC BY 2.0, from Wikimedia Commons
As an example, let's consider bow hunting. Fermentation and bow hunting require similar knowledge systems. The knowledge required for bow hunting with poison tipped arrows would surely have benefited early fermentation attempts. Attributes like pharmacology and botanical know-how would have been helpful in both occupations.

The bow and arrow points excavated at Klasies River and Sibudu are delicate items. It is unlikely they could kill an antelope outright. Rather, the purpose of the projectile point is to pierce the hide of the antelope that it is shot at, and to deliver its poison load.

It's from this technology that archaeologists have deduced that poison was part of the bow hunting technology used by the people living at Klasies River and at Sibudu.

We can say that with arrow poisons and compound adhesives, fermentation combines several ingredients to produce a novel product. What this suggests is that controlled fermentation could have occurred 25,000 to 50,000 years ago in the terminal phase of the

Middle Stone Age in Southern Africa. $\underline{3}$

We can say that with arrow poisons and compound adhesives, fermentation combines several ingredients to produce a novel product. 


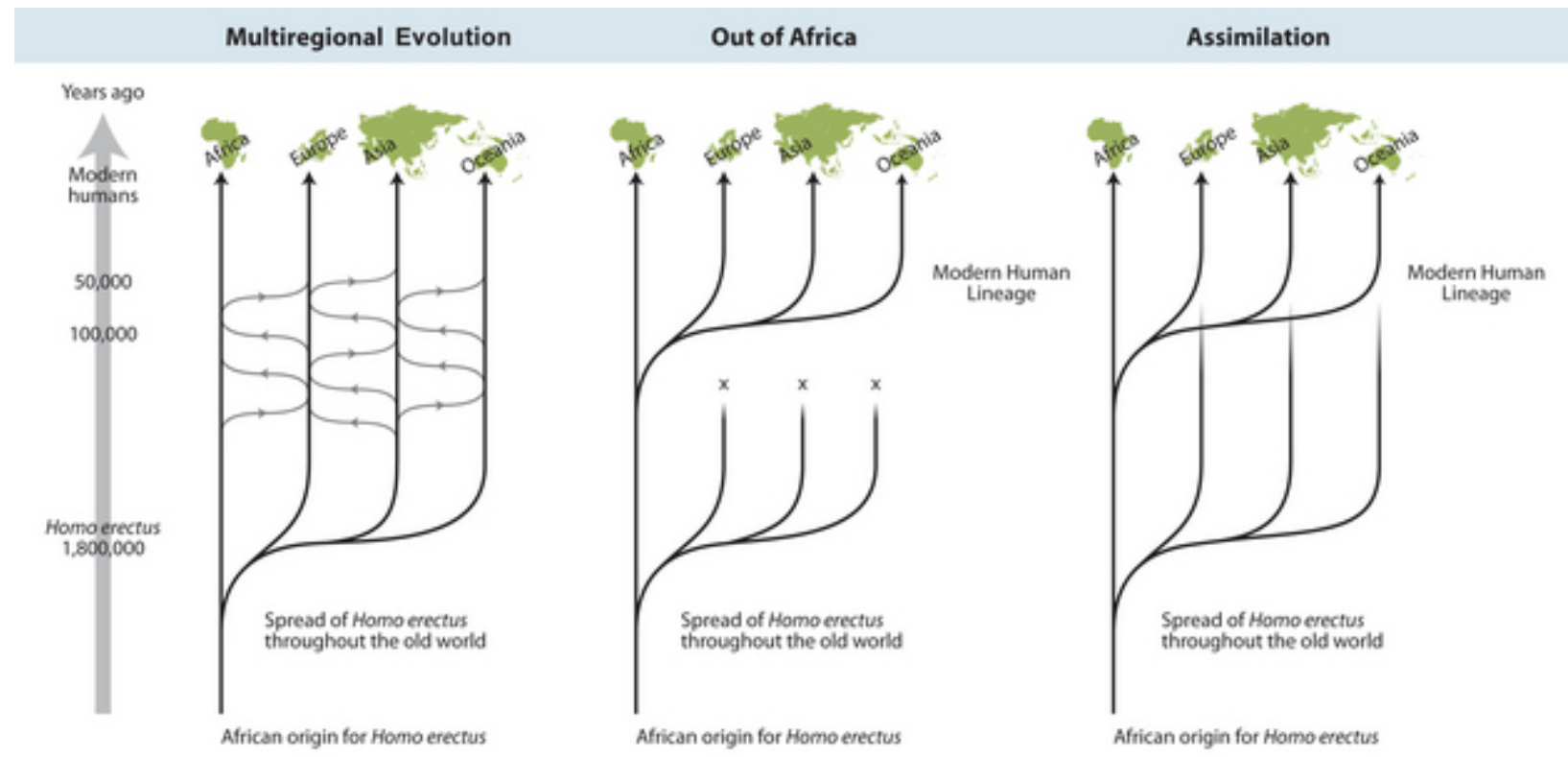

"Diagram showing each of the three competing models." (c) 2013 Nature Education Modified from Gibbons.

Accessed from Tryon, C. \& Bailey, S. (2013) Testing Models of Modern Human Origins with Archaeology and Anatomy. Nature Education Knowledge 4(3):4

Richard Klein estimates the Out of Africa scenario. New evidence is being added, which means that the information is not fixed and is instead constantly changing. Nevertheless, Klein's map gives a big picture. Into the picture we can situate bow hunting and fermentation at the time depth presented thus far.

We now move from archaeology and pre-history into the ethnographic and historical time-frame. 


\section{Seyfertt's Map}

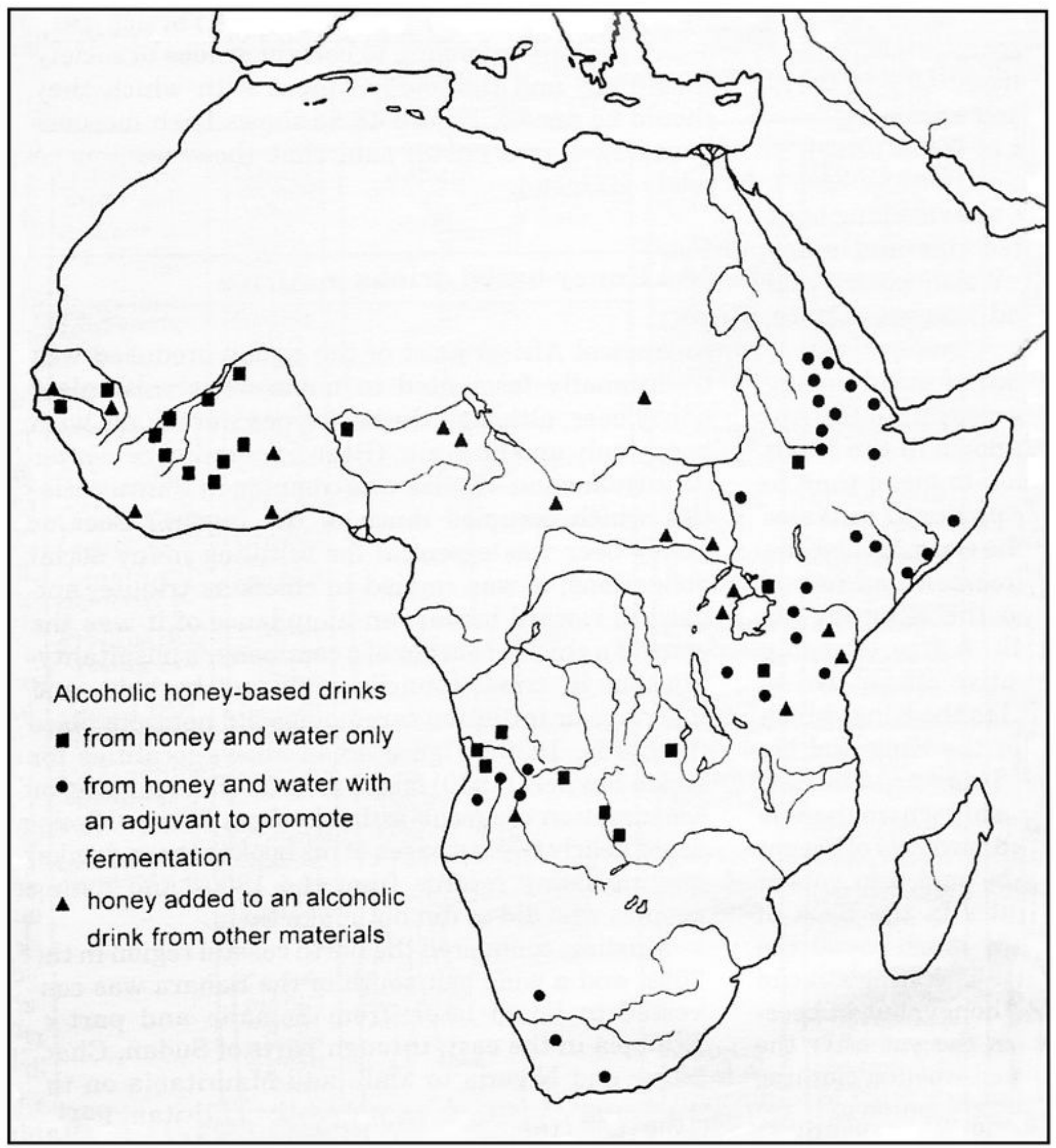

Image from Seyffert, C. (1930). Biene und honig im volksleben der afrikaner... R.

\section{Voigtländer. (C) Unknown}

My enquiry follows a multi-proxy approach, which I consider by beginning with Seyfertt's map. He shows the locations of honey-alcohol production across Africa as he recorded it a century ago. He also documented fermentation procedures with and without plant adjuncts.[ㅍ] 
This map reflects what Europeans encountered in the 18th and 19th centuries, but it is incomplete.

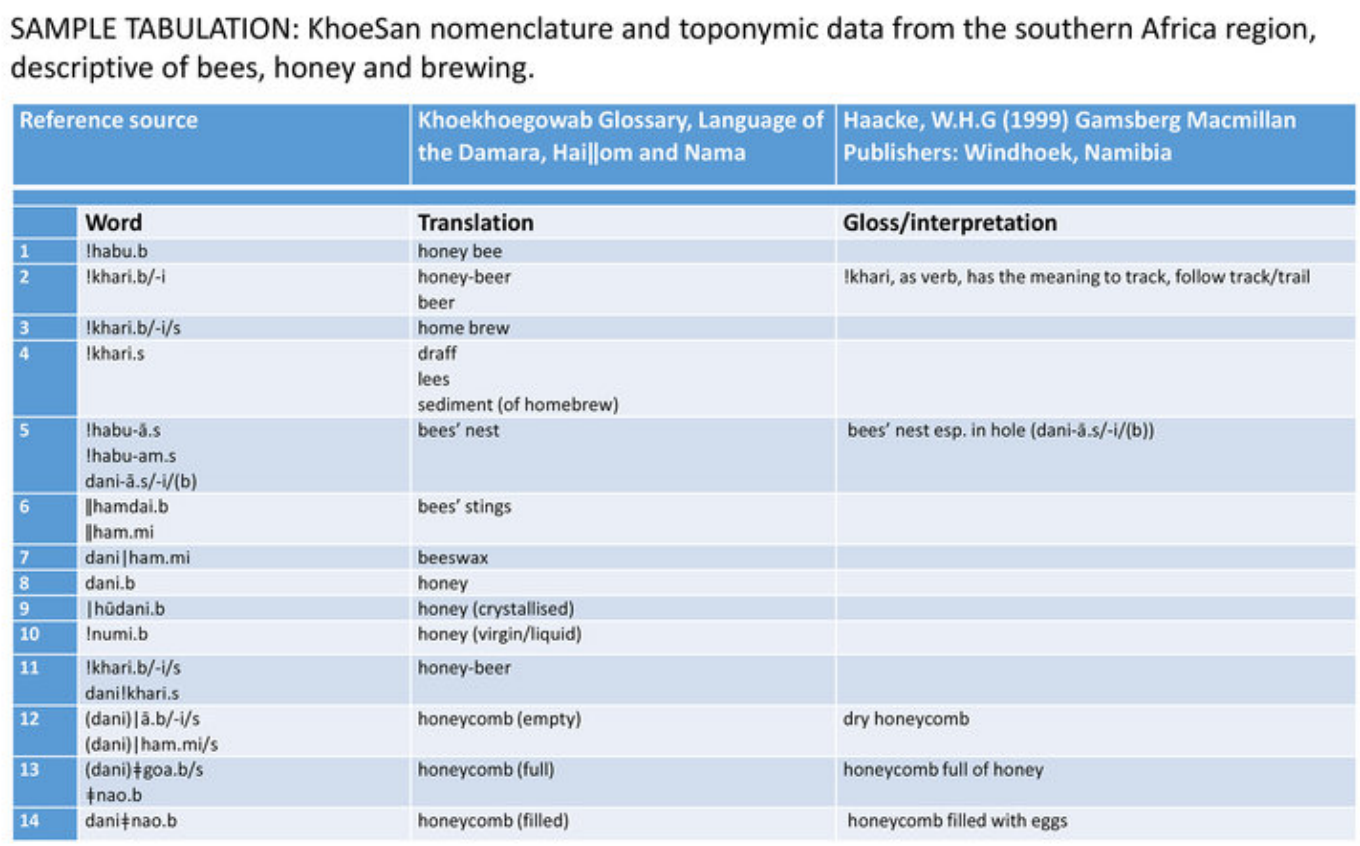

Rusch, N. 2020. Controlled fermentation, honey, bees and alcohol: archaeological and ethnohistorical evidence from southern Africa. Southern African Humanities 33: 1-31. Pinker S., (2004) Language as an adaptation to the cognitive niche, in Language Evolution, ed.. Christensen, H., and Kirby S. Oxford: Oxford University Press.

\section{Rusch, Neil. (2021). Honey, Toxicity \& Intoxication.}

My tabulation gives some of the plants used for fermentation and brewing in southern Africa, including psychoactive plants that were fermented with honey. My full tabulation is several pages long and is available by request on ResearchGate.[4]

This map represents some of the data from the previous tabulation. Seyfrett's map is by no means a complete reflection of what African people were brewing. Yet, the data, again, brings to the fore the close association between arrow poison and fermentation.

Another proxy indicator are the KhoeSan words about bees, honey and brewing, which takes us beyond the estimate of ethno-historic time frame. Exactly how far depends on which linguist you talk to.

There's a considerable knowledge here about bees, honey and brewing. The words come from several languages, some extinct, others terminal, some still spoken. The English language has no equivalent for many of these words. 


\section{Cultural Expressions}

\section{Painting}

Of course rock paintings, the painted landscape of Southern Africa, adds further evidence of a continuing preoccupation with bees. These themed paintings are recognizable in several ways:

- Catenary curves that recall honeycombs

- Ladders for access to bee nests

- Bees with red bodies and white wings

- And threads of light, or bee-lines

An example are the catenary curves, representative of honey comb, attached to the belly of the eland. $\underline{4}$
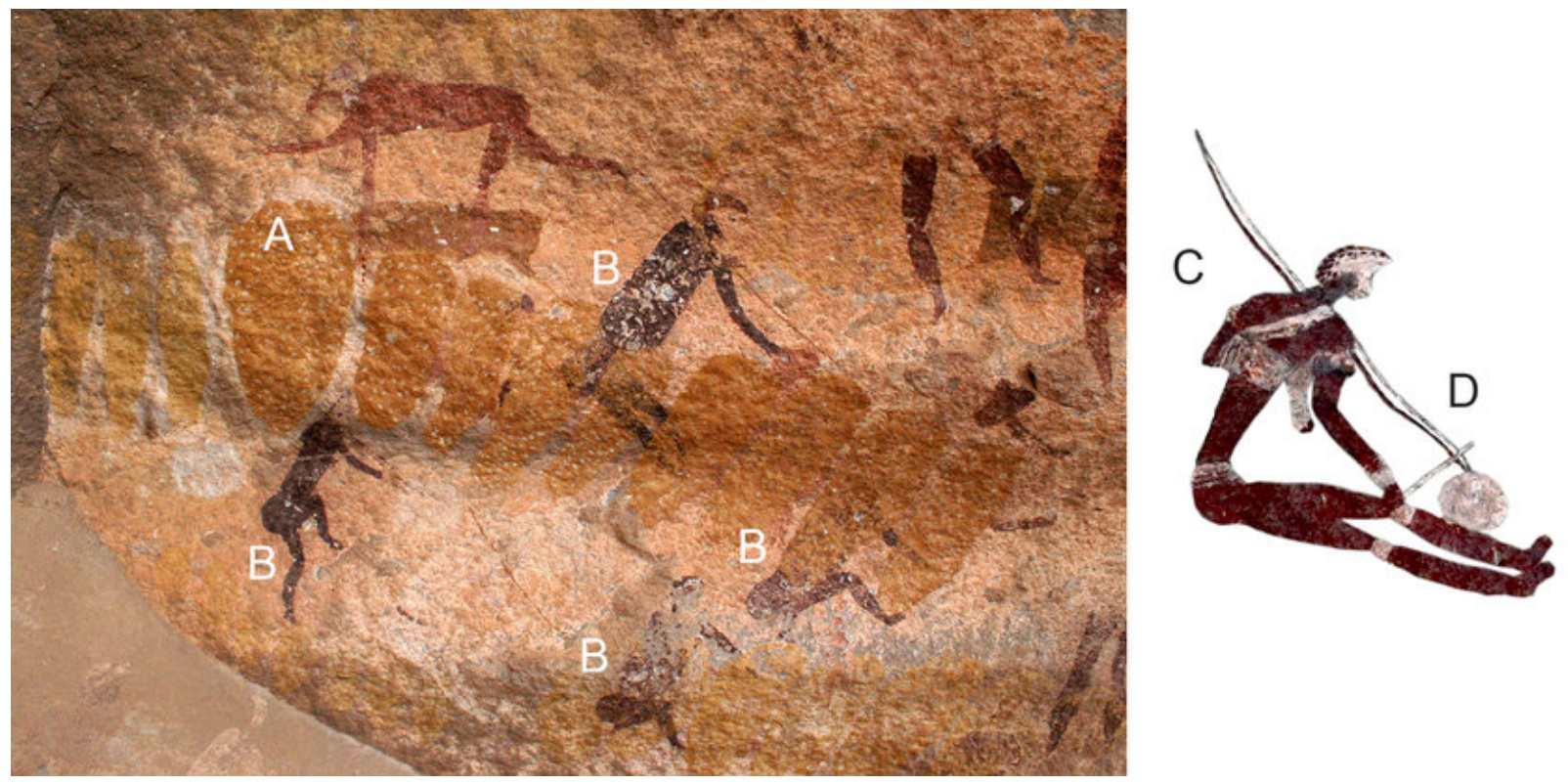

“A) Ochre-coloured honey combs superimposed on two of the four musicians (B) who are holding musical bows. Although preservation is poor there is sufficient detail to suggest that at one time these figures may have looked similar to the example in the inset (C), in which the seated figure is shown playing a musical bow, with resonator, using a stick to beat the string (D). See also Lewis-Williams \& Challis 2011:Plate 21 and Figure 37. Source: Author, personal archive" Rusch, Neil. (2017). Sound artefacts: Recreating and reconnecting the sound of the !goin !goin with the southern San Bushmen and bees. Hunter Gatherer Research 3(2). DOI $\underline{10.3828 / \text { hgr.2017.11 }}$ 


\section{Mythology}

Then these too are embedded in mythology. For example, the Southern San became known as People of the Eland. And so, for People of the Eland, there would have been no eland if in the beginning the leather that was to become the eland had not been fed with honey.

Antelope, too, would not have had any color if they had not been rubbed with different honey. According to Qing's testimony, most honey and wax are magical substances.

\section{I believe that the theme of bees and honey in southern San mythology, pictorial expression, and languages is related to the Border Cave beeswax and the exploitation of bees by early people 40,000 years ago.}

By now, it should be obvious that there are biocultural aspect to consider here. This includes the inner life of the hive. With this aerophone instrument the Xam-speaking San said they could "move bees." In other words, there is suggestion of interspecies communication. 


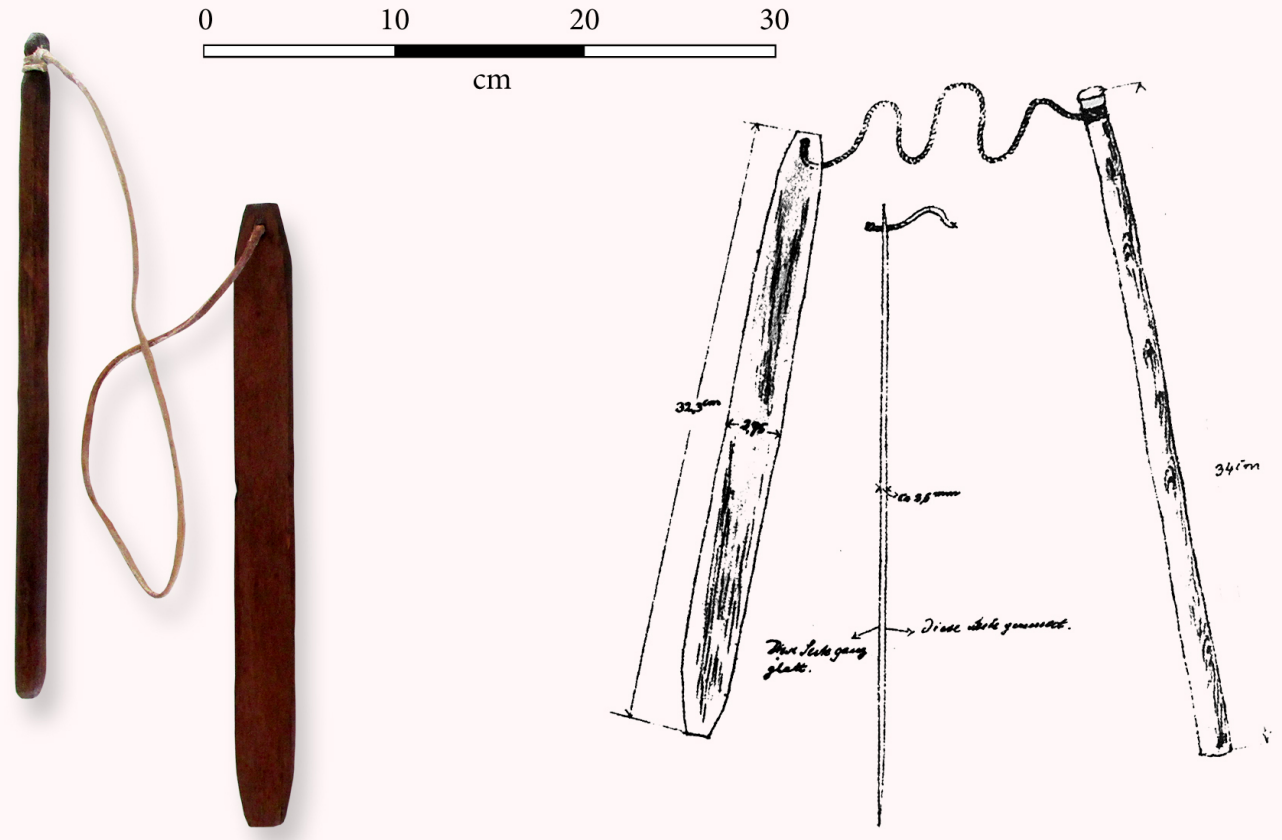

A replica of !goin !goin KK052 (left) and diagram (right). Image (c Neil Rusch. Rusch, Neil. (2017). Sound artefacts: Recreating and reconnecting the sound of the !goin !goin with the southern San Bushmen and bees. Hunter Gatherer Research 3(2). DOI 10.3828/hgr.2017.11

Now, I've replicated this instrument and we've recorded it in the sound studio. And that's what it sounds like:

- 0:00/0:19

4) : 


\section{KhoeSan Honey-Alcohol}

Let's consider the experiment:

The basic protocol follows information provided by the botanist Carl Thunberg. Traveling through southern Africa, he encountered KhoeSan people using these ingredients and method to make alcohol in the 18 th century.

The process is simple and fast. The bees provide the ingredients. Adding water and plant additives is easy to enact. And then, within 48 hours the honey-alcohol beverage contains between 2 and 3\% alcohol.

\section{I}
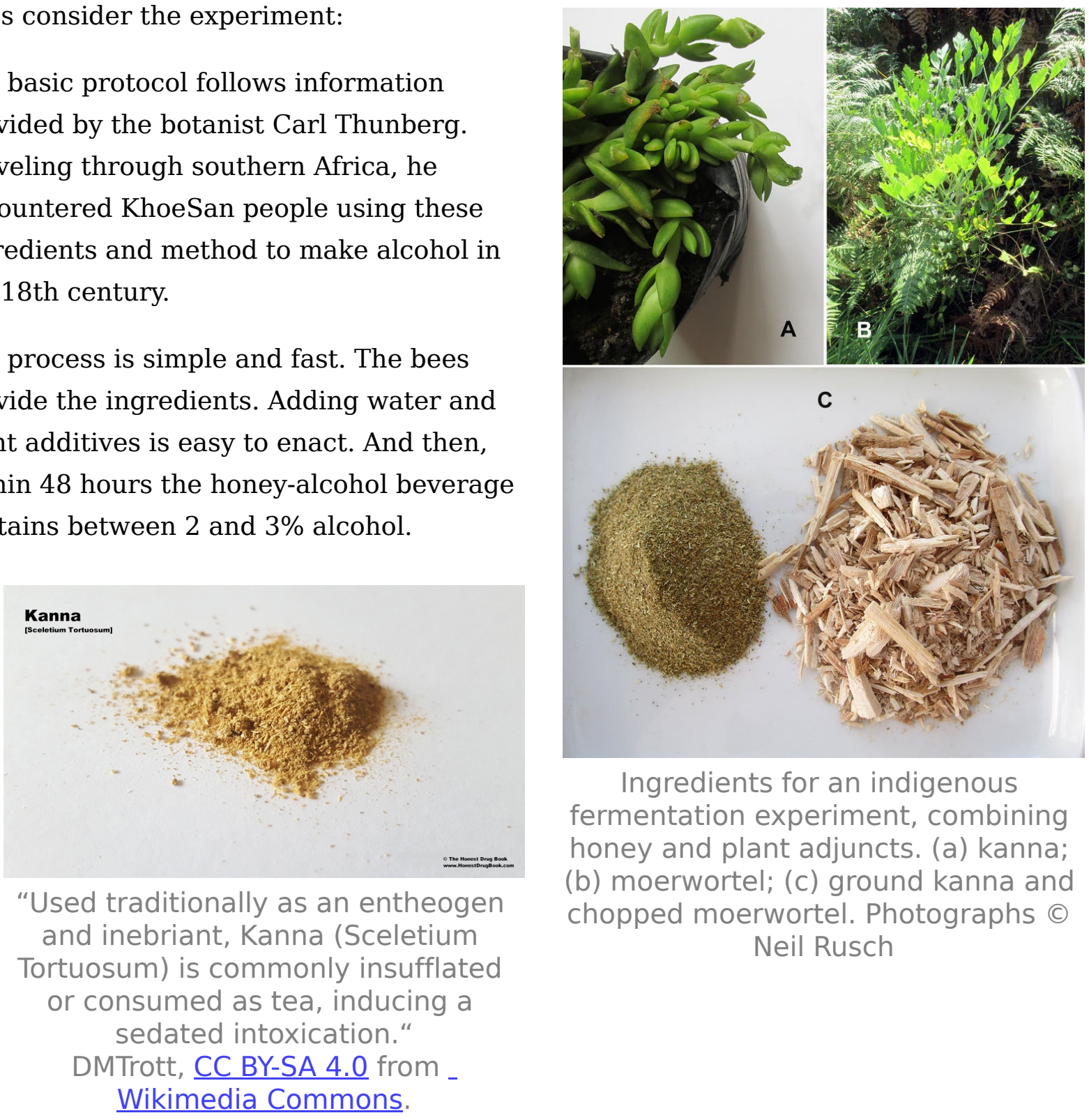

Ingredients for an indigenous fermentation experiment, combining honey and plant adjuncts. (a) kanna; (b) moerwortel; (c) ground kanna and chopped moerwortel. Photographs (c) Neil Rusch

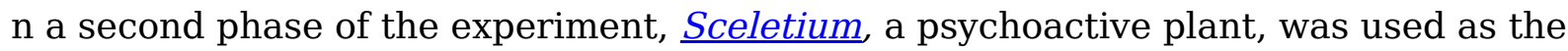
plant adjunct to produce a 'spiked' beverage called khadi.[ㅁ]

Sceletium contains alkaloids. These alkaloids are psychoactive, although they are not hallucinogenic. The mesembrine acts on brain receptors and causes serotonin reuptake inhibition. The effect of this is improved cognition, enhanced memory, better mood, and focus. 
The traditional "sweat method" enhances the alkaloids. This has been verified by two independent laboratories. Essentially the process is as follows:

1. The plant is crushed between rocks.

2. It is then put it in an envelope. Traditionally this was a leather envelope, yet nowadays, it's put in a plastic packet, Ziploc closing mechanism.

3. Then, it's left in the sun. Essentially, it undergoes fermentation.

4. After a couple of days, it's taken out. And then it's dried, and it can be chewed.

The Afrikaans word for that was $\underline{\text { Kougoed. }}$. Chewing material, chewing stuff. But we do have ethnographic information which tells us that it was used also in a honey alcohol drink.

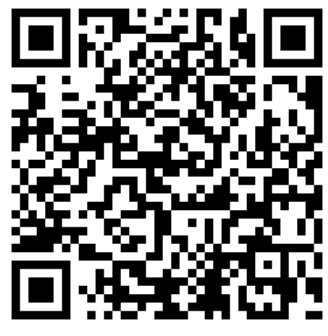

To learn more about Kougoed, or Sceletium tortuosum, use the above QR code. 

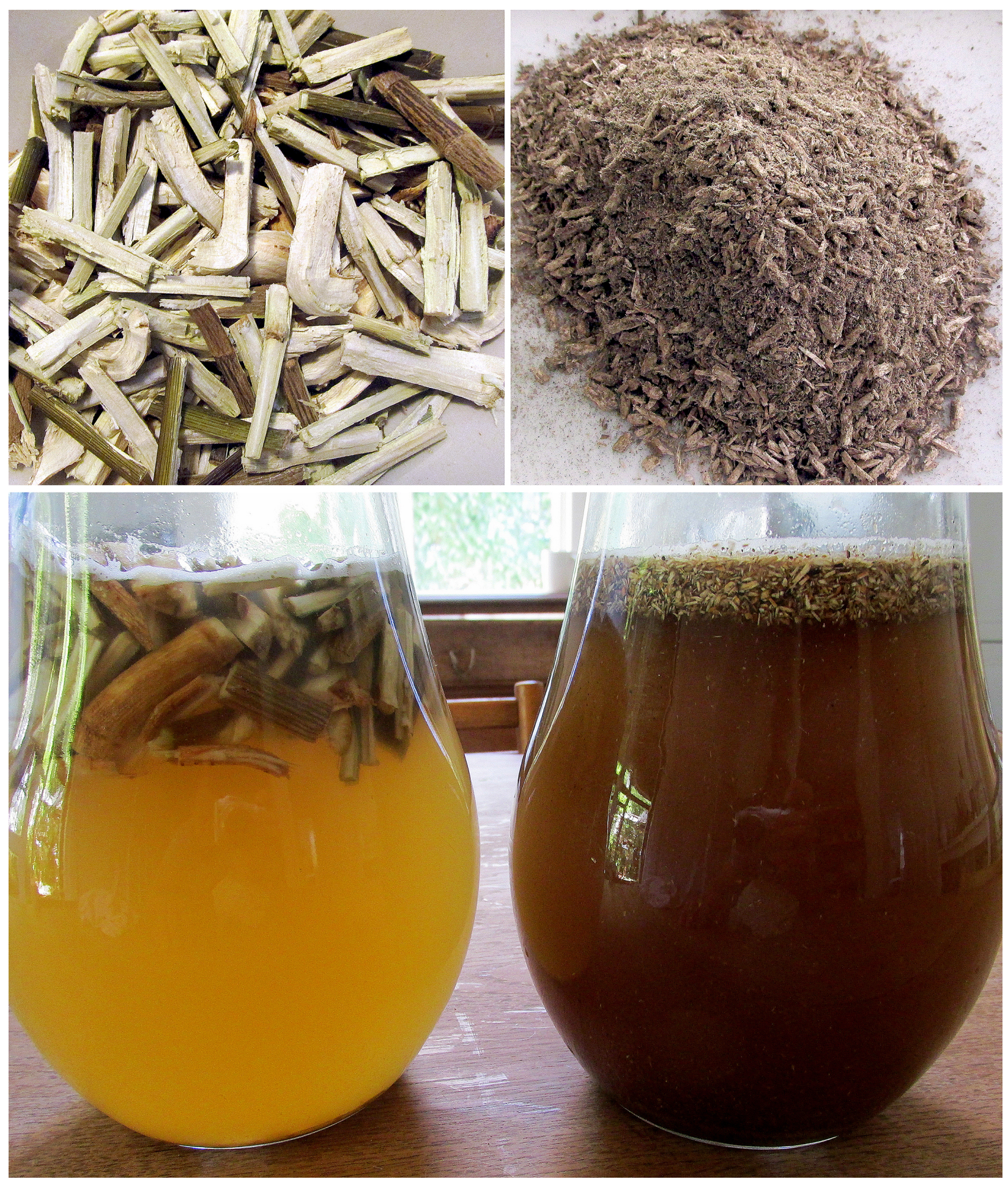

These are the materials that are assembled for the experiment. Image (c) Neil Rusch. 


\section{The Mind and Fermentation}

So we've really been speaking about, when we speak of alcohol and fermentation, is altered states of the human mind. According to Robin Dunbar, it's been a long social affair.[]]

Altered states of the human mind are connected with fermentation and alcohol. From

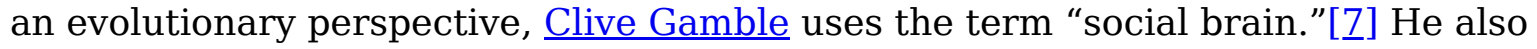
speaks of "a release from proximity," or what we would call off-line thinking. []ㅡㄹ

The questions there are: What role did psychoactive substances play, in the release from proximity? Did alcohol and Sceletium enhance group synchronization? What about the release of endorphins?

I think all these questions are worth pursuing. In my endeavors to answer some of these questions, I've begun experimenting with fermenting honey-alcohol "in the rocks" as it was said to have occurred in the 1700 s.

\section{Visit the web version of this article to view interactive content.}

\section{Fermentation Timelapse}

\section{In summary}

1. Alcohol was likely an item in the Homo sapiens shopping basket long before anyone imagined, and thus fermentation has been with us a very, very long time.

2. Honey was the most likely catalyst, used to produce the first alcoholic beverage. It's a very simple process. It doesn't mean malting, as you have with grains. As I've emphasized, it is just adding water.

3. The attempt to identify honey fermentation supplements research on honey and its significance for human evolution, social behavior, and early paleo diets. 


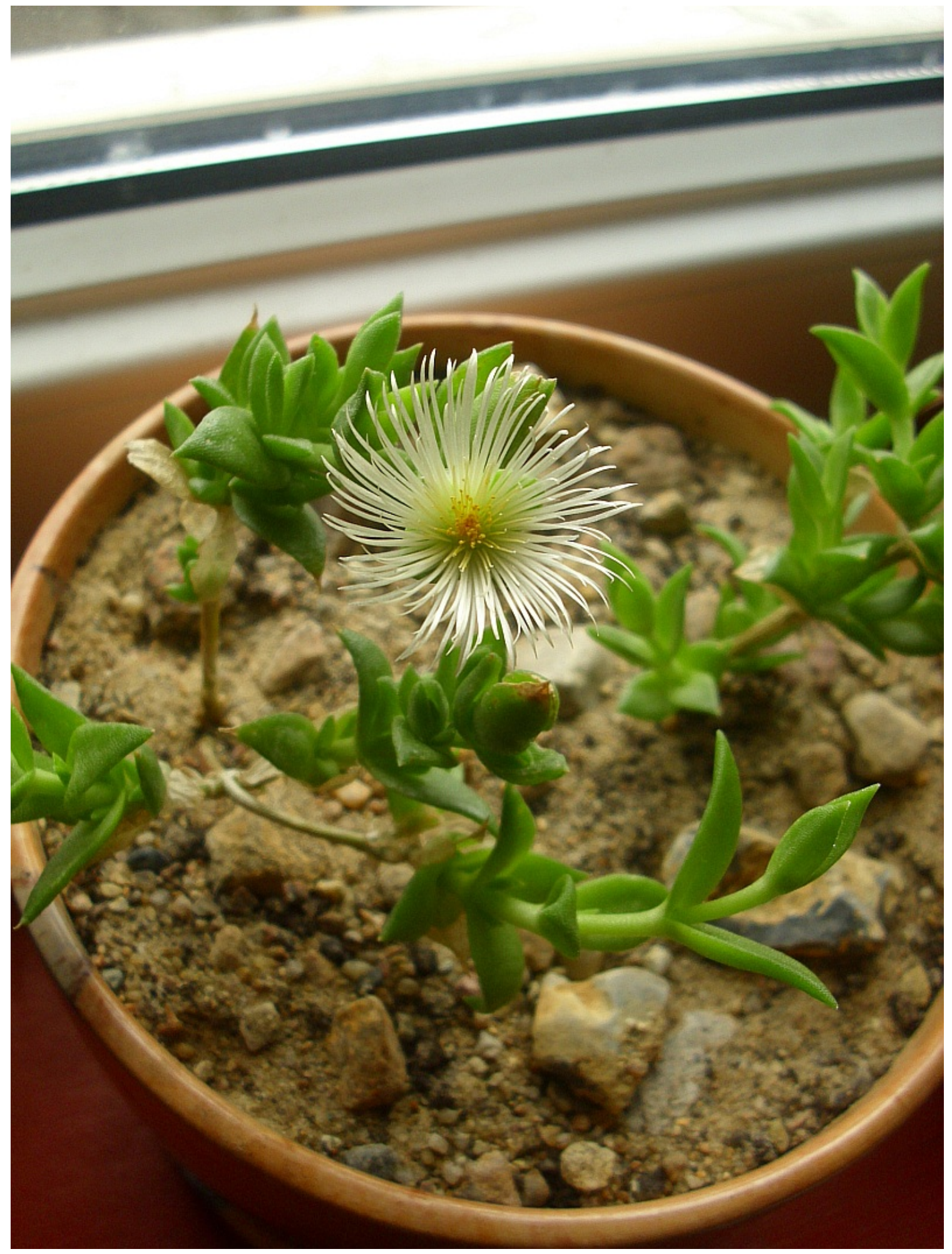

Kanna. Joozwa, CC BY-SA 3.0, via Wikimedia Commons 


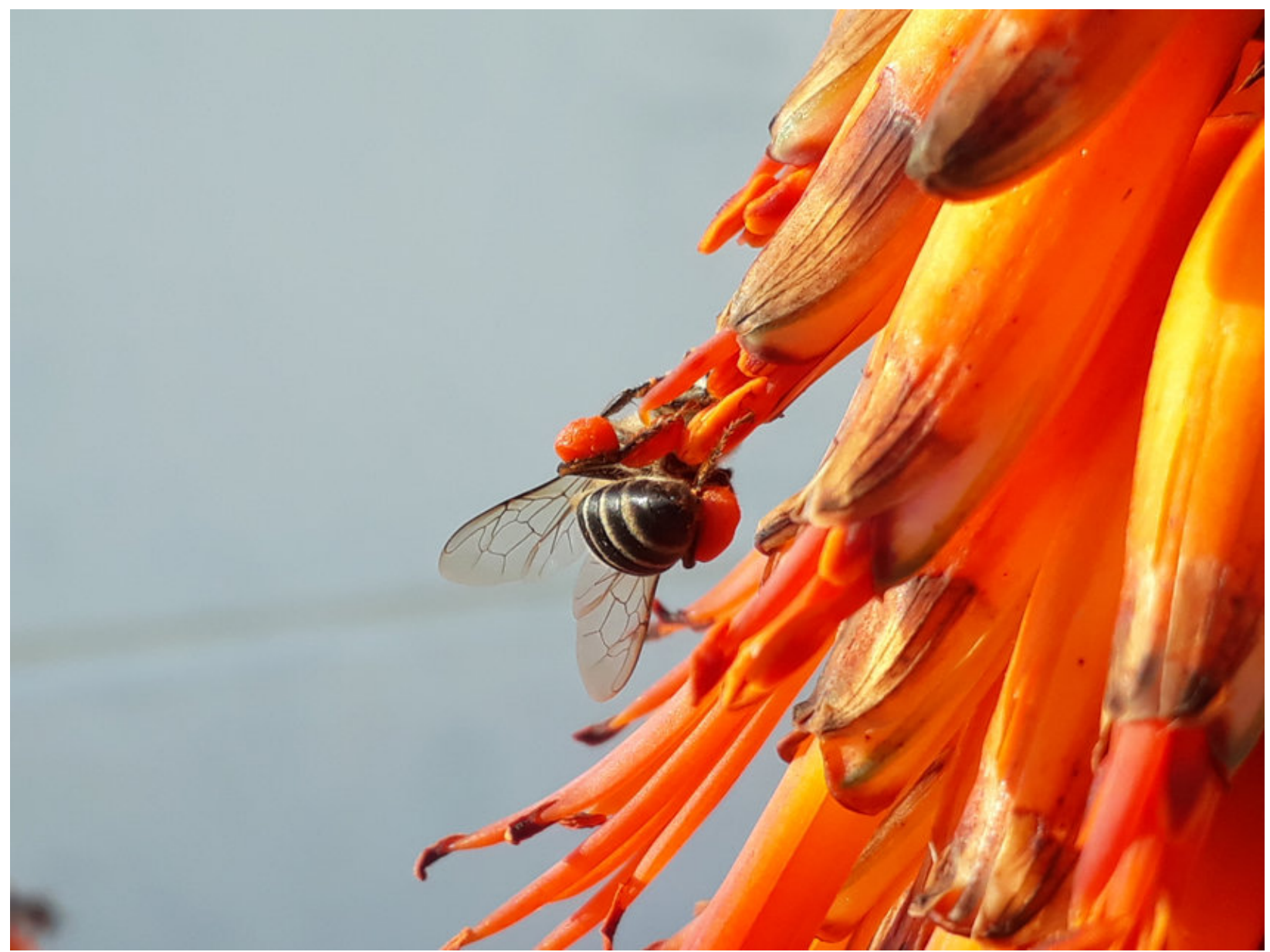

"Aloe blossoms provide a source of nectar and hollow Quiver tree trunks are inhabited by African honeybees, Apis meliffera scutellata and other creatures." Rusch, Neil. (2021). Agave log hives, dryland honeybees and the rain's magic power.

\section{Footnotes}

1. 
Explore Rusch's project $\underline{\text { Agave Honey Bee (LOG) Hive: }}$

“Bees are sentient and share a collective, independent intelligence. We respect this.

The aim of our project is to provide nest habitats that are attractive to bees and are naturally self-populating. Following traditional practice we use logs provided by the Agave. These tough plants have remarkable insulation, are lightweight and are extremely strong due to the organic integrity of the sisal fibres. The logs are harvested after the plant has grown to full maturity, has flowered, died and become dry.

Our methods are informed by African beekeeping, in particular the use of log hives and tree beekeeping practices. We are cognizant of African bee TEK (traditional ecological knowledge). Also, we remain sensitive to the mythological status accorded to bees and how this informs bio-cultural beliefs.

Our educational approach follows processes of knowledge sharing and networking (KSN) in a context of transformative learning. We also believe in policy advocacy and an ethical appreciation of bees and all that they stand for." $\bullet$

2. To learn more about this beeswax, and the other artifacts that have been discovered at Border Cave, read Does alcohol have an undisclosed African heritage? on The Conversation.

3. To learn more, read "Does alcohol have an undisclosed African heritage?" by Neil Rusch, as published in The Conversation (June 9, 2020). $\subseteq$

4. The image Dr. Rusch uses here is viewable online at the Harald Pager Collection, South African Rock Art Digital Archive. Rock Art Research Institute (RARI) controls the copyright and requests that images not be reproduced without permission. These and other images are contextualized in: Rusch, Neil. Sound artefacts. Hunter Gatherer Research: Volume 3, Issue 2. Liverpool University Press, May 2017. https://doi.org/10.3828/hgr.2017.11

\section{Citations}

1. Heil, C., \& Lahue, C. (2021). The Evolutionary History of Bread and Beer Yeast [enriched transcript]. In The Book of Fermentology (1st ed.). NC State University 
Libraries. https://doi.org/10.52750/526619

2. López-Uribe, M., \& Lawrence, B. (2021). The Biology of the Bread that Bees Make [enriched transcript]. In The Book of Fermentology (1st ed.). NC State University Libraries. https://fermentology.pubpub.org/pub/beebread/release/5 $\triangleq$

3. Seyffert, C. (1930). Biene und honig im volksleben der afrikaner: mit besonderer berücksichtigung der bienenzucht, ihrer entstehung und verbreitung. ein beitrag zur völkerkunde und kulturgeschichte, besonders afrikas, mit 15 textabbildungen und 4 verbreitungskarten (Ser. Veröffentlichungen des staatlichsächsischen forschungsinstitutes für völkerkunde in leipzig. 1. reihe. ethnographie und ethnologie. 3. bd). R. Voigtländer. $\subseteq$

4. Rusch, Neil. (2020). Controlled fermentation, honey, bees and alcohol: archaeological and ethnohistorical evidence from southern Africa. Southern African Humanities. 33. 1-31. https://journals.co.za/doi/10.10520/EJC-1e2a35c417

5. Zhou, Nerve \& Lebani, Kebaneilwe \& Motlhanka, Koketso. (2020). Fermentative Microbes of Khadi, a Traditional Alcoholic Beverage of Botswana. Fermentation. 6. 10.3390/fermentation6020051.

6. Hockings, K., \& Dunbar, R. (Eds.), Alcohol and Humans: A Long and Social Affair. : Oxford University Press.

https://oxford.universitypressscholarship.com/view/10.1093/oso/9780198842460.001. $\underline{0001 / \text { oso-9780198842460. }}$.

7.

Gamble, C., Gowlett, J., \& Dunbar, R. (2011). The social brain and the shape of the Palaeolithic. Cambridge Archaeological Journal, 21, 115-

136. https://doi.org/10.1017/S0959774311000072

Dunbar, R., Gamble, C., \& Gowlett, J. (Eds.) (2010). Social brain, distributed mind. Oxford University Press.

Gowlett, J., Gamble, C., \& Dunbar, R. (2012). Human evolution and the archaeology_ of the social brain. Current Anthropology, 53(6), 693-

722. https://doi.org $\angle 10.1086 / 667994$

8. Gamble, C. (1998). Palaeolithic society and the release from proximity: a network approach to intimate relations. World Archaeology, 29(3), 426-

449. https://doi.org/10.1080/00438243.1998.9980389 $ヒ$ 